\title{
Reactive Mass Transfer of Single NO Bubbles and Bubble Bouncing in Aqueous Ferric Solutions - A Feasibility Study
}

\author{
Mark W. Hlawitschka ${ }^{1 *}$, Martin Oßberger ${ }^{2}$, Christian Backes', Peter Klüfers ${ }^{2}$ and Hans-Jörg Bart ${ }^{1}$ \\ ${ }^{1}$ Chair of Separation Science and Technology, Center for Mathematical and Computational Modelling (CM)', \\ University of Kaiserslautern, P.O. Box 3049, 67653 Kaiserslautern - Germany \\ ${ }^{2}$ Department Chemie der Ludwig-Maximilians-Universität München, Butenandtstraße 5 - 13, 81377 München - Germany \\ e-mail: mark.hlawitschka@mv.uni-kl.de \\ * Corresponding author
}

\begin{abstract}
Reactive bubble columns are widely used in the chemical, petrochemical, biochemical and metal industries. While the reactive mass transfer around a single spherical shaped bubble is quite well described in literature, the influence of hydrodynamic interactions, such as bubble bouncing or coalescence on mass transfer - with and without chemical reaction - is not well understood. As to this, high resolution simulations and sophisticated experimental analysis based on high-speed camera images and local color changes gives a new firm basis. In this work, a new system is presented, based on Nitric Oxide (NO) gas absorbed in a Fe ${ }^{I I}$-solution. The reaction rate can be adjusted by the addition of ligands and the resulting local color change is detected. The impact of the colliding bubbles leads to a deformation of the bubble shapes and creates a fast movement of the bubble interfaces, which, finally, leads to an increased mass transfer. The results of five tested ligands reveal the high potential of the reactive $F e^{I I}(N O)$ system to investigate basic phenomena affecting yield and selectivity of mixing-sensitive chemical reactions.
\end{abstract}

Résumé - Transfert de masse réactive de bulles simples et de bulles rebondissantes dans les solutions ferriques aqueuses - Une étude de faisabilité - Les colonnes à bulles réactives sont largement utilisées dans les industries chimiques, pétrochimiques, biochimiques et métalliques. Bien que le transfert de masse réactif autour d'une seule bulle de forme sphérique soit assez bien décrit dans la littérature, l'influence des interactions hydrodynamiques, comme le rebond des bulles ou la coalescence sur le transfert de masse - avec ou sans réaction chimique - n'est pas bien comprise. Pour ce faire, des simulations de haute résolution et des analyses expérimentales sophistiquées basées sur des images de caméras à haute vitesse et des changements de couleur locaux donnent une nouvelle base solide. Dans ce travail, un nouveau système est présenté, basé sur l'oxyde nitrique (NO) gazeux absorbé dans une solution de $\mathrm{Fe}^{\mathrm{II}}$. La vitesse de réaction peut être ajustée par addition de ligands et le changement de couleur local résultant est détecté. L'impact des bulles de collision entraîne une déformation des formes de bulles et crée un mouvement rapide des interfaces de bulles, ce qui conduit finalement à un transfert de masse accru. Les résultats de cinq ligands testés révèlent le haut potentiel du système réactif $\mathrm{Fe}^{\mathrm{II}}(\mathrm{NO})$ pour étudier les phénomènes fondamentaux affectant le rendement et la sélectivité des réactions chimiques sensibles au mélange. 


\section{INTRODUCTION}

Gas-liquid reaction systems are encountered in several fields of application such as hydro-formylation, alkylation, carboxylation, polymerization, hydrometallurgy, biochemical processes and fine chemicals manufacturing. In recent years, experiments focused on single mass transfer with rising bubbles to obtain a better understanding of local effects [1] such as wake shedding, bubble contamination [2-6], pH influence [7] and local mass transfer [1, 8-11]. With the aid of Computational-Fluid-Dynamics (CFD) simulations, local hydrodynamics can be resolved and give further information in respect to local modeling of mass transfer [12-16]. Koynov and Khinast [17] investigated the effect of hydrodynamics on chemically reacting bubble flows using Direct Numerical Simulations (DNS). The observed wake characteristic varied significantly with the bubble shape and the fluid property. At low Reynolds numbers $(8<\mathrm{Re})$ the wake is closed and stable. Up to a Reynolds number of 52, two symmetric recirculation zones were observed in the wake of the bubbles. As the Reynolds number increases, the recirculation zones become longer and unstable. At higher Reynolds numbers, the wake detaches from the bubble and forms a vortex-shedding flow downstream. The three different wake structures affect the yields and selectivity of mixing-sensitive chemical reactions. The swarm influence on chemical reactions was studied in Koynov et al. [18], while a significant influence on the reaction selectivity could be observed for mixing sensitive reactions. Nevertheless, the simulations were case studies and a direct validation with experimental data is missing.

As a reactive test system, the chemisorption of $\mathrm{CO}_{2}$ in water is reported in literature [19-21] mainly to investigate the overall reactor behavior. The mass transfer with and without reaction was studied by Houghton [22] using a carbon dioxide-MonoEthanolAmine (MEA) system. A single bubble was fixed at a bubble support (needle). MEA was pumped around the bubble, while the size of the bubble was kept constant by adjusting the volumetric gas flow. Numerical techniques have been extended to describe forced-convection mass transfer from single bubbles with and without overlapping reactions. Wylock et al. [23] studied the reactive absorption of carbon dioxide in aqueous sodium bicarbonate and sodium carbonate at a gas-liquid interface by digital holographic interferometry. The oxidation reaction of sodium sulfitesulfate catalyzed with cobalt was investigated by Kück et al. [9] for single bubbles. Laser Induced Fluorescence (LIF) was applied to detect the concentration profiles and Particle Image Velocimetry (PIV) to obtain the flow field around the bubble.

The works in literature deal with complex reaction systems (parallel reactions) and lack by a description of bubble interactions and their effect on reactive mass transfer. In contrast to this the purpose of our study is to investigate the principles of reactive mass transfer using a well-defined system, such as Nitric Oxide (NO) and $\mathrm{Fe}^{\mathrm{II}}$ chelate complexes, allowing a tunable reaction kinetics by the addition of ligands.

\section{REACTIVE SYSTEM FE"(NO)}

Nitric oxide can be regarded as one of the most intriguing molecules of chemistry. This small diatomic molecule with its unpaired electron was formerly well known for its toxic impact on the environment and the human body, since it is unavoidably produced during the combustion of fossil fuels. In the 1980s researchers discovered the other side of this chameleon-like molecule. To their surprise, it was found to be a gaseous hormone in the human body. Accordingly, in 1992 the magazine Science nominated NO as the "molecule of the year". NO can be regarded as an important cellular signaling molecule involved in many physiological and pathological processes. The interaction of NO with iron centers of hemoproteins [24] and nonheme enzymes with cysteine environment [25] plays an important role in its biological activity. To put it simply, the formation of a $\mathrm{Fe}(\mathrm{L})-\mathrm{NO}$ bond (L means ligand) triggers the opening of a blood vessel. This discovery was awarded with the Nobel Prize in Medicine or Physiology in 1998 [26] and led to the design of a variety of coordination complexes to understand the structural and reactive properties of $\mathrm{Fe}(\mathrm{L})-\mathrm{NO}$ systems [27, 28].

The fundamental reaction (without coligand) follows in many cases the scheme:

$$
\mathrm{Fe}^{2+}(\mathrm{aq})+\mathrm{NO}(\mathrm{g}) \leftrightarrows[\mathrm{Fe}(\mathrm{NO})]^{2+}(\mathrm{aq})
$$

This represents a classical text-book reaction: the brownring test for nitrate. In an acidic medium, NO formed by nitrate reduction coordinates to aquated $\mathrm{Fe}^{2+}$ producing the typical brown colour. Schneppensieper and co-workers found that reaction (1) occurs through a dissociative interchange mechanism, where water is exchanged by the nucleophile NO [29] which reaction (2) shows in a more detailed scheme.

$$
\left[\mathrm{Fe}\left(\mathrm{H}_{2} \mathrm{O}\right)_{6}\right]^{2+}+\mathrm{NO} \leftrightarrows\left[\mathrm{Fe}\left(\mathrm{H}_{2} \mathrm{O}\right)_{5}(\mathrm{NO})\right]^{2+}+\mathrm{H}_{2} \mathrm{O}
$$

They measured a fast rate-constant $\left(k_{\mathrm{f}}=1.6 \times\right.$ $10^{6} \mathrm{M}^{-1} \mathrm{~s}^{-1}$ ) of this reaction, but since the elimination of $\mathrm{NO}$ in the dissociation process of the nitrosyl complex is just a bit slower $\left(k_{\mathrm{d}}=3.2 \times 10^{3} \mathrm{M}^{-1} \mathrm{~s}^{-1}\right)$, the stability of the nitrosyl complex resulted in a moderate constant [30]. In order to raise the stability, chelate ligands of the amine 
TABLE 1

Overview of selected ligands and their respective stability constants [30].

\begin{tabular}{c|c|c|c|c|c|c}
\hline & No coligand & Ligand 1 & Ligand 2 & Ligand 3 & Ligand 4 & Ligand 5 \\
\hline Name & - & oda & ida & edda & edta & hedtra \\
\hline$K_{\mathrm{no}}\left[\mathrm{M}^{-1}\right]$ & $1.2 \times 10^{3}$ & $4.3 \times 10^{3}$ & $1.2 \times 10^{4}$ & $3.3 \times 10^{5}$ & $2.1 \times 10^{6}$ & $1.5 \times 10^{7}$ \\
\hline
\end{tabular}

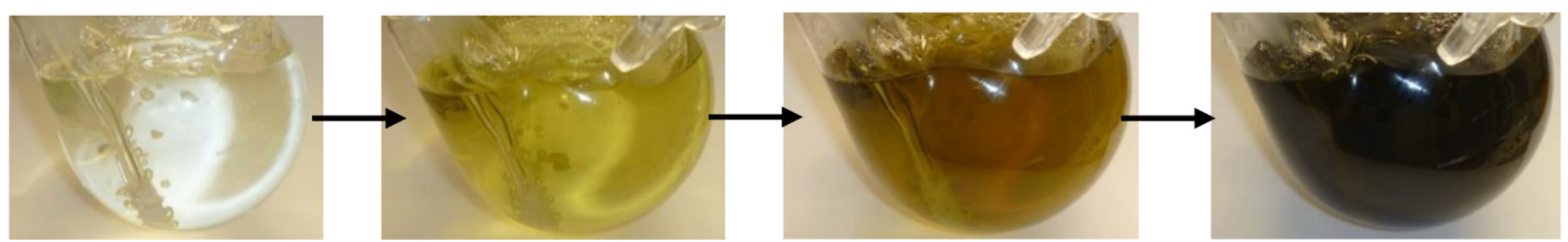

Scheme 1

Course of $\mathrm{Fe}(\mathrm{L})-\mathrm{NO}$ formation in a Schlenk flask. NO initiation $(100 \mathrm{mg} / \mathrm{min})$ in a solution of $\mathrm{Fe}(\mathrm{L})(\mathrm{c}(\mathrm{Fe})>0 \mathrm{mM})$. Reaction time: up to $10 \mathrm{~min}$.

carboxylato group were added to the aqueous ferrous solution prior to NO initiation. In the reaction Scheme $(3,4)$ the distinct deprotonated ligand IminoDiacetic Acid (IDA) is used for clarity.

$$
\begin{gathered}
{\left[\mathrm{Fe}\left(\mathrm{H}_{2} \mathrm{O}\right)_{6}\right]^{2+}+\mathrm{ida}^{2-} \leftrightarrows\left[\mathrm{Fe}\left(\mathrm{H}_{2} \mathrm{O}\right)_{3}(\mathrm{ida})\right]+3 \mathrm{H}_{2} \mathrm{O}} \\
{\left[\mathrm{Fe}\left(\mathrm{H}_{2} \mathrm{O}\right)_{3}(\mathrm{ida})\right]+\mathrm{NO} \leftrightarrows\left[\mathrm{Fe}\left(\mathrm{H}_{2} \mathrm{O}\right)_{2}(\mathrm{ida})(\mathrm{NO})\right]+\mathrm{H}_{2} \mathrm{O}}
\end{gathered}
$$

As seen in reaction (4), the target complex $\mathrm{Fe}^{\mathrm{II}}(\mathrm{L})-\mathrm{NO}$ still binds two water molecules. Thus, other ligands with more metal-binding sites (e.g. edda, edta, hedtra) can be introduced, replacing water.

Stability constants of the $\mathrm{Fe}^{\mathrm{II}}(\mathrm{L})-\mathrm{NO}$ complexes increased from $1.2 \times 10^{3} \mathrm{M}^{-1}\left(\mathrm{~L}=\mathrm{H}_{2} \mathrm{O}\right)$ up to $1.5 \times$ $10^{7} \mathrm{M}^{-1}(\mathrm{~L}=$ hedtra $)$. A series of different amine carboxylate ligands settled between these two positions. van Eldik's [28-30] systematic study indicated that the ability to bind NO is strongly affected by the selected chelating ligands. This gives a powerful tool to design a $\mathrm{Fe}^{\mathrm{II}}-\mathrm{NO}$ complex with distinct stability and formation velocity in respect to the proposed application. A selection of possible ligands and their respective $\mathrm{Fe}^{\mathrm{II}}(\mathrm{L})(\mathrm{NO})$ stability constants $K_{\mathrm{NO}}$ are shown in Table 1. Having just water in its coordination sphere, the "pure" $\mathrm{Fe}^{\mathrm{II}}(\mathrm{NO})$ complex showed the lowest stability constant, while using the edta and hedtra ligands, the complexes exhibited the highest values.

The high stability of the complex $\mathrm{Fe}^{\mathrm{II}}$ (edta)(NO) for instance is applied in a Chemical Absorption-Biological Reduction (CABR) process, also called BIODeNO ${ }_{\mathrm{x}}$. This cost-effective and "green" NO removal technology for coal-fired power plants has claimed several current publications [31-39].

In principle, the removal of NO from exhaust gas streams into an aqueous phase by pure absorption is slow. The amount of dissolved NO is proportional to its partial pressure in the gas phase and can be described by the Henry's constant. Sander [40] gives a value of $1.9 \times 10^{-5} \mathrm{~mol} \mathrm{~m}^{-3} \mathrm{~Pa}^{-1}$ for $\mathrm{NO}$ in water. In the CABR process, the high reaction rate in water of a ferrous ethylenediaminetetraacetate solution with $\mathrm{NO}$ is used to enhance the NO mass transfer, resulting in a better NO removal efficiency. Within a reductive biological environment or even a biofilm electrode reactor, NO is subsequently reduced to harmless $\mathrm{N}_{2}$, regenerating $\mathrm{Fe}^{\mathrm{II}}$ (edta) as NO absorbant. As an up-to-date technology this system qualifies as a model reaction for two-phase investigations studying the interaction of chemical and physical phenomena. It is attractive to test these systems in scale-up frameworks such as bubble columns, because they deal with controllable reactivity, inexpensive starting materials, water as a reaction medium and a fast color change from bright yellow to dark brown on coordination of NO (Scheme 1). Hence, mass transfer be easily monitored by light-sensitive techniques.

From a chemical viewpoint, the stability of the $\mathrm{Fe}^{\mathrm{II}}(\mathrm{L})-\mathrm{NO}$-system is not fully understood since the exact mechanism of the product formation and the rules of the relationship of structure and feature are, to our knowledge, still unknown. In two forthcoming publications [41, 42], the research group of Klüfers tries to fill this gap based on knowledge of structural characterization of $\mathrm{Fe}^{\mathrm{II}}(\mathrm{L})(\mathrm{NO})$ complexes with amincarboxylato coligands. 


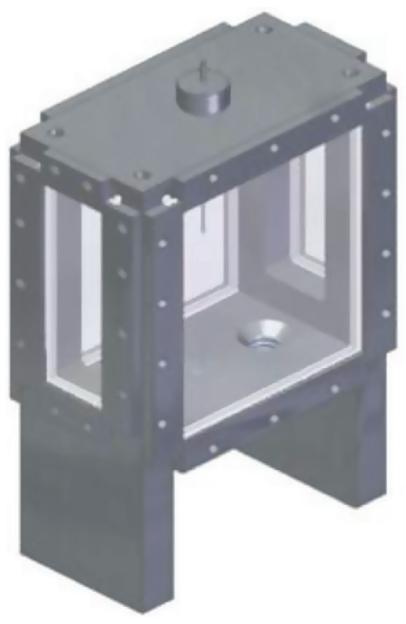

a)

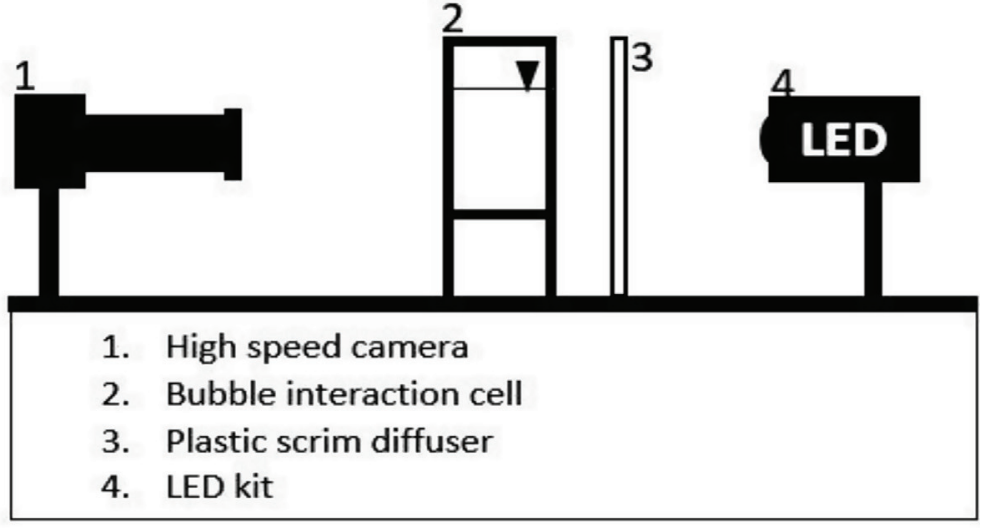

b)

Figure 1

a) Single bubble interaction cell. b) Sketch of the camera measurement system setup.

TABLE 2

Possible resolutions of the camera system used at a frame rate of $4000 \mathrm{fps}$ in dependence on the image size.

\begin{tabular}{c|c}
\hline Image size (longest edge) & Resolution \\
\hline $\mathrm{mm}$ & $\mu \mathrm{m} / \mathrm{pixel}$ \\
\hline 5 & 3.9 \\
\hline 10 & 7.8 \\
\hline 15 & 11.7 \\
\hline 20 & 15.6 \\
\hline 25 & 19.5 \\
\hline 50 & 39.1 \\
\hline
\end{tabular}

\section{EXPERIMENTAL}

\subsection{Experimental Setup}

The cuboidal bubble interaction apparatus with its dimensions of $90 \times 55 \times 115 \mathrm{~mm}$ is similar to the one used for liquid-liquid systems [4] (Fig. 1). Side windows on each side guarantee optical accessibility from the four side plates. The apparatus is built using stainless steel, glass and PTFE pipes. This allows an adequate cleaning to avoid impurity accumulation between each experiment. In contrast to the apparatus used for liquid-liquid systems, a top plate is mounted to avoid direct contact with the surrounding air and to decrease a possible contamination. For the detection of the bubbles, we used an Imaging Solutions NX-8S2 camera in combination with a macro $100 \mathrm{~mm}$ lens.

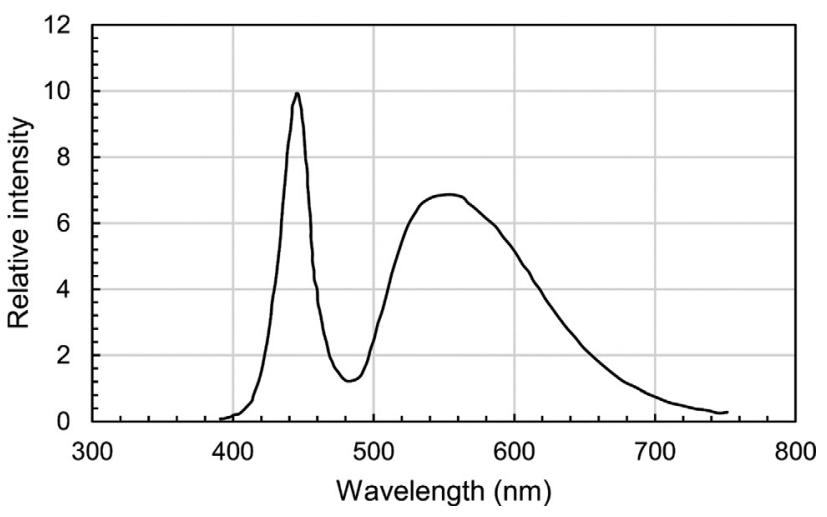

Figure 2

Spectral data of the LED which corresponds to the extinction coefficient of the $\mathrm{Fe}^{\mathrm{II}}-\mathrm{NO}$ complexes at $430-460 \mathrm{~nm}$.

The camera has a maximum resolution of $1600 \times 1280 \mathrm{pixel}^{2}$ at 4000 frames per second. The achievable resolutions for this frame rate are shown in Table 2.

The frame rate can be increased to a reasonable range of resolution $\left(1600 \times 300 \mathrm{pixel}^{2}\right)$ up to $14000 \mathrm{fps}$. As the light source, a Constellation 120E LED kit is used with an aperture angle of $15^{\circ}$ and 5000 lumens. The LED light can be operated in (triggered) pulsed or continuous mode. The camera is triggered by the internal software, which recognizes the movement of bubbles in the observed image section. The spectral data of the LED is shown in Figure 2, with a significant intensity peak at $445 \mathrm{~nm}$.

The full experimental setup is depicted in Figure 3. The argon gas cylinder is connected to the Spectrocem regulator FE51-SP3 mounted on the NO gas cylinder. 


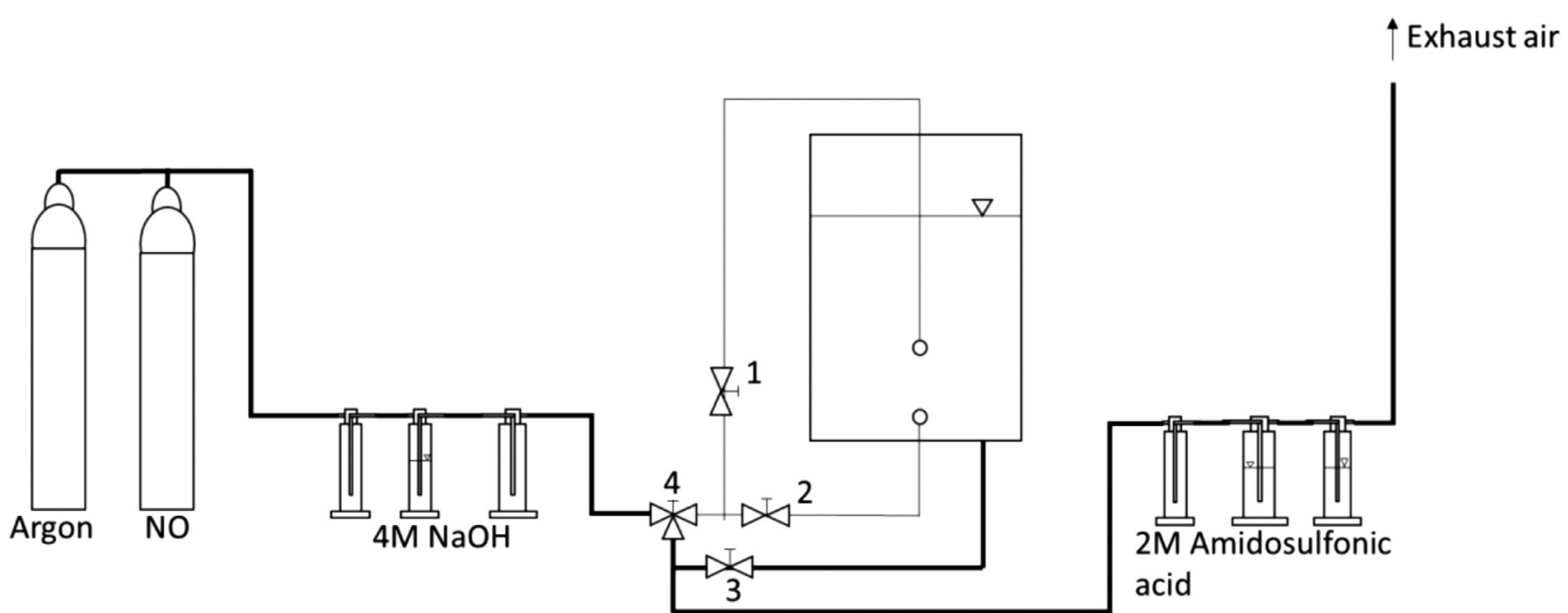

\section{Magnetic valve \\ 2 Magnetic valve 3 Valve for degassing}

Figure 3

Detailed sketch of the experimental setup.

TABLE 3

Properties of the applied system.

\begin{tabular}{c|c|c}
\hline Property & Value & \\
\hline Molar mass & $0.03 \mathrm{~kg} \mathrm{~mol}^{-1}$ & \\
\hline Density NO & $1.34 \mathrm{~kg} \mathrm{~m}^{-3}$ & \\
\hline Density water & $998.2 \mathrm{~kg} \mathrm{~m}^{-3}$ & {$[46]$} \\
\hline Diffusion coefficient NO & $1 \times 10^{-9} \mathrm{~m}^{2} \mathrm{~s}^{-1}$ & Own data $\left(25^{\circ} \mathrm{C}\right)$ \\
\hline Mass transfer coefficient NO & $2.54-3.56 \times 10^{-5} \mathrm{~m} \mathrm{~s}^{-1}$ & \\
\hline
\end{tabular}

From there, a tube is connected to three washing bottles, where the middle one is filled with a four molar $\mathrm{NaOH}$ solution. Valve 1 and valve 2 are connected to the needles, generating the bubbles inside the cell. Valve 3 can be opened for a better degassing of the initial liquid with argon. Using valve 4 , the gas in the main pipes can be directed to the exhaust air. Unreacted NO is destroyed by $2 \mathrm{M}$ amidosulfonic acid.

In general, the experimental setup allows investigations of the bubble rise and bubble/interface as well as bubble/bubble interaction using less than $500 \mathrm{~mL}$ of surrounding liquid. In the case of bubble/bubble interaction, the cannula distance, where the bubbles are generated, is adjustable up to $100 \mathrm{~mm}$. This allows an investigation of bubble collision at different bubble rise velocities.

\subsection{Experimental Preparation and Physical Properties}

Reversed osmosis water (conductivity: $<0.2 \mu \mathrm{S} / \mathrm{cm}$ ) is filled into the apparatus and afterwards degassed for at least 45 min with argon, which forms, in addition, an inert layer at the top of the apparatus. Afterwards, the appropriate amount of $\mathrm{Fe}^{\mathrm{II}}$ complex is added with the desired amount of ligand, resulting in a slightly yellow solution. All the experiments are at room temperature in a range of $23{ }^{\circ} \mathrm{C} \pm 1{ }^{\circ} \mathrm{C}$.

The gas is switched from argon to NO, while the valves to the needles are closed and valve 4 is opened to the exhaust gas. This guarantees that only a small amount of argon is left in the apparatus setup. Finally, valve 4 is closed again and valves 1 and 2 are opened, to reduce argon in the tubes 
TABLE 4

Study of different ligands and its effect on the wake concentration.

\begin{tabular}{|c|c|c|c|c|c|c|}
\hline \multirow{2}{*}{$\begin{array}{c}\text { Name } \\
\text { (*see Appendix) }\end{array}$} & No coligand & Ligand 1 & Ligand 2 & Ligand 3 & Ligand 4 & Ligand 5 \\
\hline & - & oda & ida & edda & edta & hedtra \\
\hline \multicolumn{7}{|l|}{$\begin{array}{c}\text { Bubble } \\
\text { representation }\end{array}$} \\
\hline $\begin{array}{c}\text { Speed where } \\
\text { picture was taken }\end{array}$ & $0.30 \mathrm{~m} \mathrm{~s}^{-1}$ & $0.28 \mathrm{~m} \mathrm{~s}^{-1}$ & $0.29 \mathrm{~m} \mathrm{~s}^{-1}$ & $0.29 \mathrm{~m} \mathrm{~s}^{-1}$ & $0.28 \mathrm{~m} \mathrm{~s}^{-1}$ & $0.28 \mathrm{~m} \mathrm{~s}^{-1}$ \\
\hline Size & $2.8 \mathrm{~mm}$ & $2.8 \mathrm{~mm}$ & $2.8 \mathrm{~mm}$ & $2.8 \mathrm{~mm}$ & $2.9 \mathrm{~mm}$ & $2.7 \mathrm{~mm}$ \\
\hline Camera & \multicolumn{6}{|c|}{ Imaging Solutions NX-8S2 } \\
\hline Lens & \multicolumn{6}{|c|}{ Tamron Makro $100 \mathrm{~mm} \mathrm{f2,8}$ with "C for Nikon" - Adapter } \\
\hline Filter & \multicolumn{6}{|c|}{ TECHSPECH Blue M55.0 $\times 0.75$ imaging filter } \\
\hline Aperture & \multicolumn{6}{|c|}{ f8 } \\
\hline Exposure time & \multicolumn{6}{|c|}{$2.4 \times 10^{-5} \mathrm{~s}$} \\
\hline $\begin{array}{l}\text { Frames per } \\
\text { second }\end{array}$ & \multicolumn{6}{|c|}{$4000 \mathrm{fps}$} \\
\hline Focus length & \multicolumn{6}{|c|}{$0.4 \mathrm{~m}$} \\
\hline Temperature & \multicolumn{6}{|c|}{$23 \pm 1{ }^{\circ} \mathrm{C}$} \\
\hline
\end{tabular}

leading to the needles. The main properties for the $\mathrm{Fe}^{\mathrm{II}}(\mathrm{NO})$ system are depicted in Table 3. A first evaluation of the respective mass transfer coefficient was performed in a counter-current flow setup. The counter-current flow setup consists of a convergent-divergent nozzle as main part. The principle setup was previously used for investigations of droplet-droplet interactions and is reported in Simon [43]. The used nozzle has a total length of $210 \mathrm{~mm}$, a maximum diameter of DN80 at the ends and a minimum inner diameter of $30 \mathrm{~mm}$. The droplet generation was replaced by a needle valve and a needle having a diameter of $1 \mathrm{~mm}$ ranging inside the column. For flow homogenization, a wired mesh, wire diameter of $1 \mathrm{~mm}$ and wire distance of $5 \mathrm{~mm}$, was installed $150 \mathrm{~mm}$ above the convergentdivergent nozzle. The bubble was generated, flowing upwards until it is kept by the counter-current flow inside the nozzle. The change in bubble size was recorded by a high speed camera. The shrinkage of the 34 bubbles from $3.8 \mathrm{~mm}$ down to $2.1 \mathrm{~mm}$ was investigated and resulted in a mass transfer coefficient value in the range of $2.54 \times 10^{-5}$ up to $3.56 \times 10^{-5} \mathrm{~m} \mathrm{~s}^{-1}$ at $25^{\circ} \mathrm{C}$. This is in good agreement with the publication of Li and Fang [44]

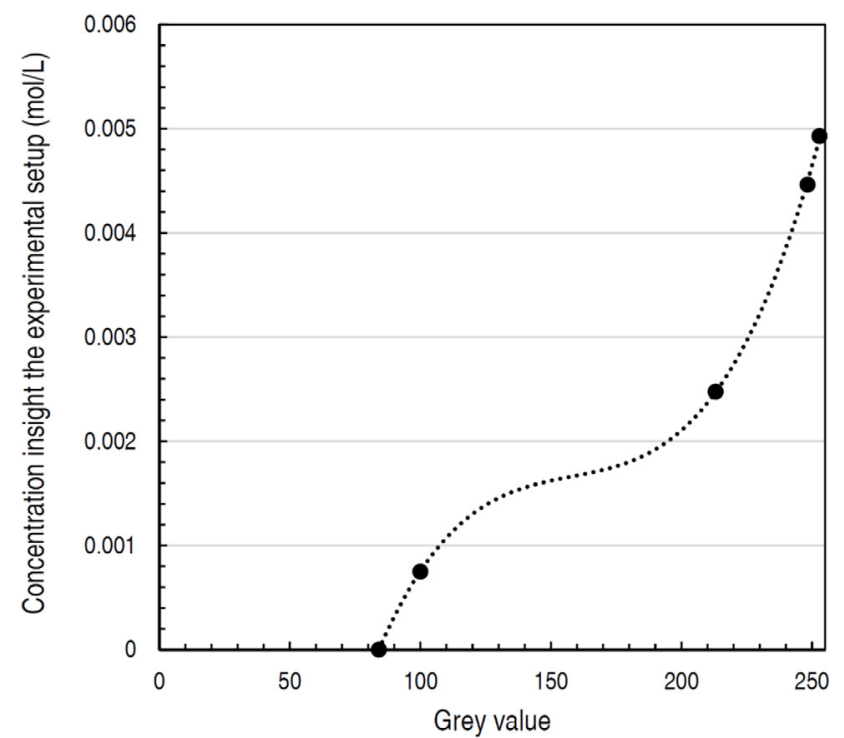

Figure 4

Calibration curve to obtain concentrations from the light intensities for the system $\mathrm{Fe}^{\mathrm{II}}$ (edta) e.g. for a characteristic concentration wake thickness of $1.1 \mathrm{~mm}$. 


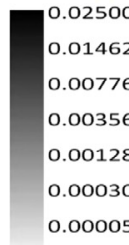

0.00000

First period

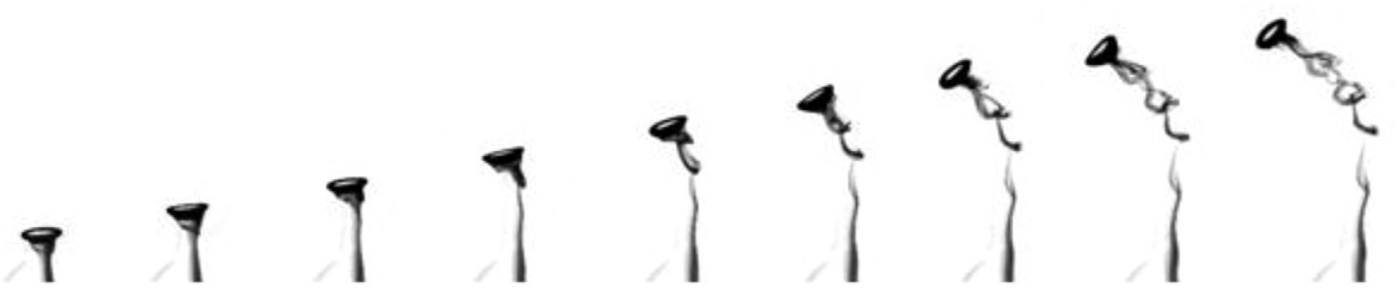

Second period
Third period

Figure 5

Rise of a single bubble. Straight upward rise in the first period, beginning of the oscillating bubble movement in the second period and in the third period, fully developed helix structure. Concentrations in the wake are in $\mathrm{mol} \mathrm{L}^{-1}$.

$\left(3.4 \times 10^{-5} \mathrm{~m} \mathrm{~s}^{-1}\right.$ at $\left.25^{\circ} \mathrm{C}\right)$ and Gambardella et al. [45] $\left(1.9 \times 10^{-5} \mathrm{~m} \mathrm{~s}^{-1}\right.$ at $\left.25^{\circ} \mathrm{C}\right)$, while the first group determined the mass transfer coefficient by physical absorption of $\mathrm{CO}_{2}$ and finally correlated the mass transfer coefficient for NO by a correction factor based on the different diffusion coefficients of the gases. The second group investigated the physical mass transfer of $\mathrm{N}_{2} \mathrm{O}$ and corrected the mass transfer coefficient also based on the different diffusion coefficients.

\section{RESULTS AND DISCUSSION}

\subsection{Investigation of Different Ligands}

Five different ligands were investigated to study their effect on the wake concentration. The $\mathrm{Fe}^{\mathrm{II}}$-concentration was set at $0.025 \mathrm{~mol} \mathrm{~L}^{-1}$, followed by addition of $0.075 \mathrm{~mol} \mathrm{~L}^{-1}$ ligand. The ligands and the results are depicted in Table 4. For the investigations, the experimental setup as well as the camera parameters were kept identical. The bubble sizes were in a range from 2.7 to $2.9 \mathrm{~mm}$ and the bubble rise velocities differed in the range of $0.26 \mathrm{~m} \mathrm{~s}^{-1}$ (ligand 3) up to $0.32 \mathrm{~m} \mathrm{~s}^{-1}$ (ligand 2) for the taken image sequence. The NO reacted with the respective $\mathrm{Fe}^{\mathrm{II}}$-complex and a dark layer surrounding the bubbles was recorded by the camera indicating the local concentration by its grey value.

From the recorded images, ligand 4 (edta) showed the darkest greyscale in the wake structure which indicated the highest concentration of the target complex, followed by ligand 5 (hedtra). This can be well understood since the higher denticity of the chelating ligands (edta, hedtra) and the use of the deprotonated sodium adducts support the binding stability of the NO-complex. Comparing $\mathrm{Fe}^{\mathrm{II}}$ (hedtra) and $\mathrm{Fe}^{\mathrm{II}}$ (edta) the latter exhibited a higher stability versus oxygen. Hence, for single bubble experiments, edta is favorable.

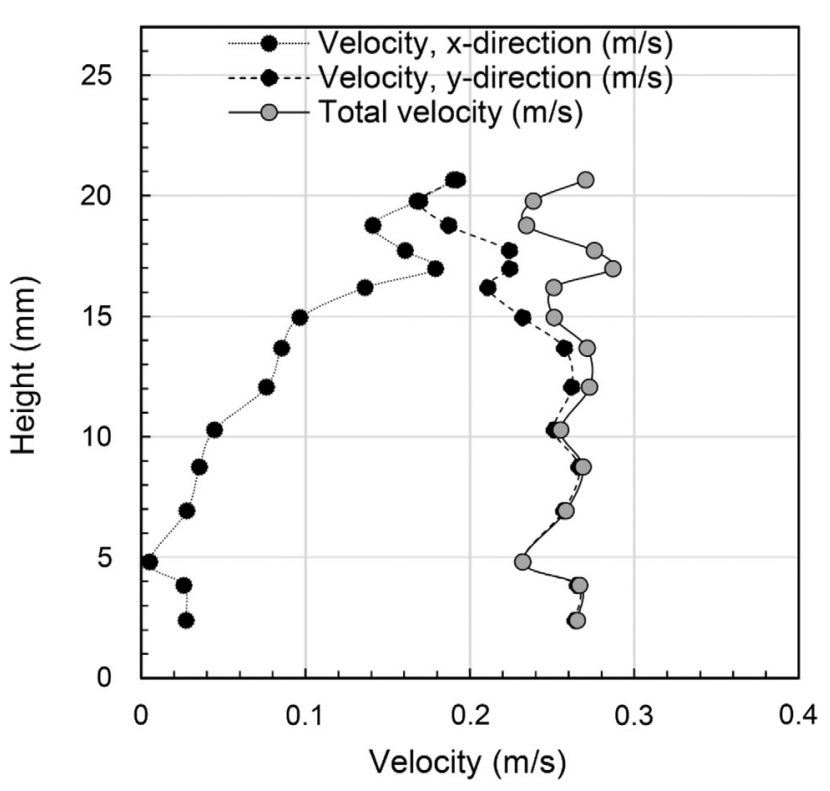

Figure 6

Bubble speed of the single bubble.

\subsection{Concentraction Measurement}

For concentration detection a calibration curve is obtained based on the Beer-Lambert law, where $E$ is the extinction, $I_{0}$ is the intensity of the emitted light, $I_{1}$ the intensity of the light passing through the cell, $l$ is the characteristic length (length of solution the light passes through, e.g. width of the cell, concentration in the wake), $\varepsilon_{\lambda}$ the molar absorptivity and $c$ as the concentration.

$$
E=\lg \left(\frac{I_{0}}{I_{1}}\right)=l \cdot \varepsilon_{\lambda} \cdot c
$$

Based on specified initial $\mathrm{Fe}^{\mathrm{II}}$ concentrations in water, NO is added, until the solution is saturated. The calibration 


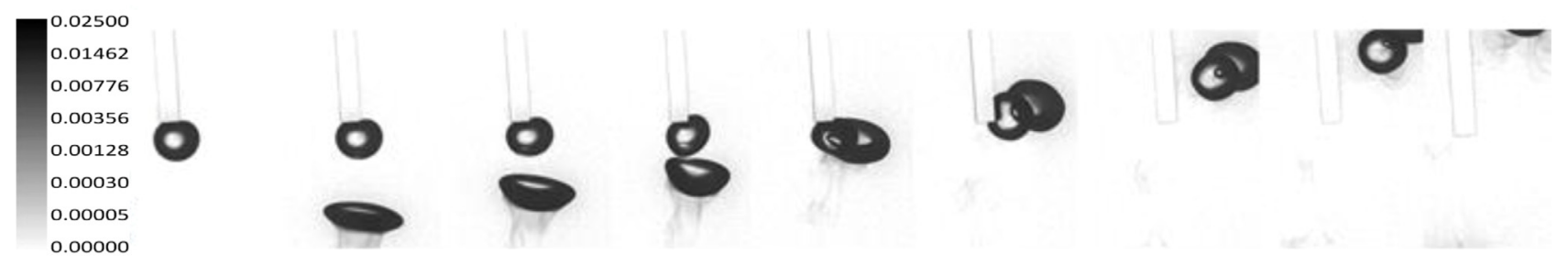

Figure 7

Interaction between $\mathrm{NO}$ and argon bubble. Concentrations are given in $\mathrm{mol} \mathrm{L}^{-1}$.

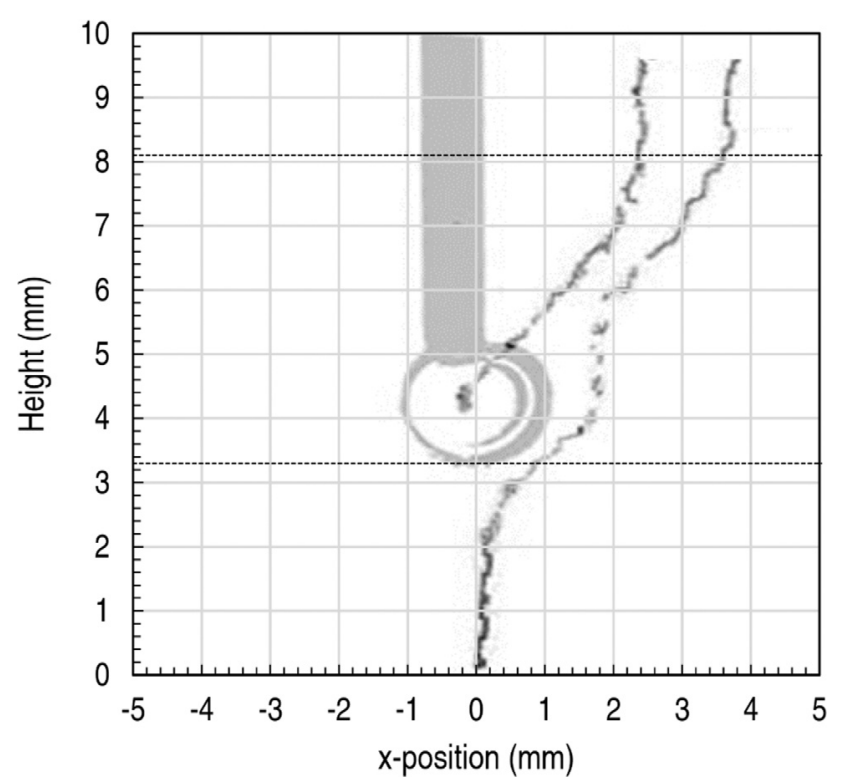

Figure 8

Path of the rising argon and NO bubbles.

curve is generated using the measured emitted and absorbed light intensities. Based on a measured extinction, the concentration corresponds on the thickness of the concentration layer $l$. Therefore, the concentration in the wake can be obtained by Equation (6), where $c_{\text {cell }}$ is the concentration based on the measurements in the cell of the width $l_{\text {cell width }}$. The width of the wake is given by $l_{\text {wake width }}$ and has to be measured at every position (Fig. 4):

$$
c_{\text {wake }}=c_{\text {cell }} \times \frac{l_{\text {cell width }}}{l_{\text {wake width }}}
$$

\subsection{Single Bubble Rise}

The bubble rise of a single NO bubble with a diameter of $2.7 \mathrm{~mm}$ in a $\mathrm{Fe}^{\mathrm{II}}$ (edta) solution is shown in Figure 5. The corresponding velocity is depicted in Figure 6.

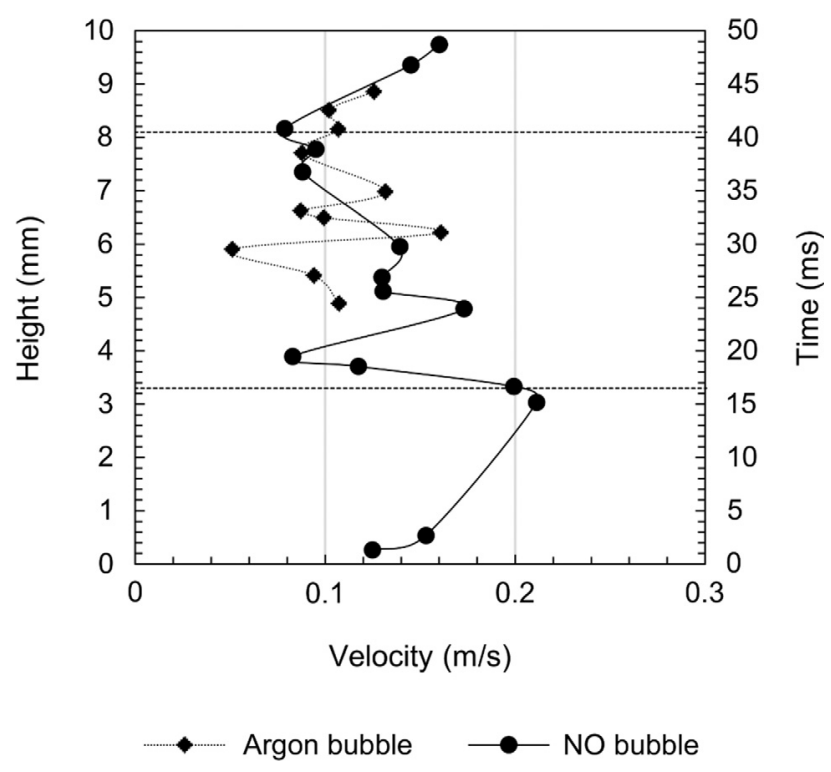

Figure 9

Velocity of the NO and the argon bubble.

In the first period, the bubble rose from the needle in a straight line and accelerated. In the second period, the oscillation of the bubble started and the concentration profile in the wake of the bubble showed a first unsteady vortexshedding. In the third period, this vortex structure formed a helix wake structure resulting in a lower bubble rise velocity.

The concentration in the wake of the bubble has its maximum at $0.0246 \mathrm{~mol} \mathrm{~L}^{-1}$. The concentration in the wake spatially remains during the observed bubble straight bubble rise period and is only slightly influenced diffusion. In the beginning of the second period, the concentration is reduced in the wake. For an investigation of the concentration in the helix wake, a second camera is required, to evaluate the thickness of the wake and hence the patch of transmitted light with high accuracy. Hence, we resign a detailed discussion about the exact concentration in this work. 


\subsection{Bubble Interaction}

To compare with the previous investigations, a second bubble was generated with a second needle. The bubble remained there, until it was influenced by the impact or wake structure of the rising bubble. Three cases were observed during impact. A centric impact led to a repulsion of the rising bubble, while an eccentric impact led to a rise of both bubbles on one side of the needle or of both bubbles on the opposite side of the needle. The side by side rise was observed when the fixed bubble stayed at the needle until it entered the wake structure of the initial rising bubble. The second one was observed, when the rising bubble pushed the bubble at the needle to the opposite side.

As an example, the repulsion of an NO bubble with a diameter of $2.8 \mathrm{~mm}$ from an argon bubble with a diameter of $2.1 \mathrm{~mm}$ is shown in Figure 7. The corresponding bubble path lines are depicted in Figure 8 indicating an eccentric bubble contact and the velocity of each bubble is shown in Figure 9.

The NO bubble accelerated during its free bubble rise (first segment). The bubble approach and, finally, the bubble/bubble interaction led to a decrease of the bubble velocity (second segment). The NO bubble hit the argon bubble eccentrically (Fig. 8) and moved along the interface until the second bubble was influenced by the wake of the NO bubble and both bubbles rose side by side. At the moment of contact, the concentration profile around the bubble seemed to decrease, while, in the upward movement of the bubbles, an increased concentration profile was observed. In the third segment, the wake structure of each bubble was reconstructed and the bubbles rose side by side.

\section{CONCLUSIONS}

A new system for the investigation of local phenomena on reactive mass transfer is presented. The reactive system $\mathrm{Fe}^{\mathrm{II}}(\mathrm{NO})$ was used to investigate the reactive mass transfer with free rising bubbles and bubbles under hydrodynamic stress conditions, namely bubble bouncing. Five different ligands were applied to investigate the effect of different reaction rates. In general, the reaction led to a colour change of the $\mathrm{Fe}^{\mathrm{II}}$-solution from slightly yellow to dark brown, which made it trackable by high-speed photography. In general, by the use of a light source with a maximum intensity in the range of the light absorption of the reaction $(430-450 \mathrm{~nm})$, the measurement system can be used to recalculate the local concentration profile.

The experiments revealed, that for single bubble experiments, concerning the intensity of the wake structure, the application of edta or hedtra showed the most promising results for single bubble experiments. By changing the ligand, the reaction rate and hence the concentration in the wake can be adjusted.

Concerning the single bubble experiments, a straight bubble rise was observed for the first millimeters until the bubble suddenly started to move to one side combined with a disturbance of the developed reaction wake structure, ending up with a formation of a helical wake structure.

Concerning the bubble interactions, the wake structure was disturbed by the impact of the second bubble. The rising bubble started to rotate. Directly after contact, a higher grey value, due to reaction, was observed.

The results of the study highlight the reactive $\mathrm{Fe}^{\mathrm{II}}(\mathrm{NO})$ system as a model for the investigation of single bubble interface. The use of different ligands acts as a regulating parameter leading the reaction velocity and product stability towards the desired application.

For full column experiments, the use of $\mathrm{Fe}^{\mathrm{II}}$ without an additional ligand may be favorable due to the possibility of stripping the solution with argon, thus eliminating NO and reusing the $\mathrm{Fe}^{\mathrm{II}}$-solution for the next experiment. Nevertheless, the application of chelating ligands may be advantageous when connecting the knowledge of chemistry with the aims of engineers, especially when it leads to a specific application as the mentioned CABR process, where edta plays a significant role. One challenge in this NO eliminating process remains the unwanted oxidation of $\mathrm{Fe}^{\mathrm{II}}$ (edta) to $\mathrm{Fe}^{\mathrm{III}}$ (edta), which no longer absorb NO. Further research may tackle this challenge of selectivity by shifting the existing competition between NO uptake of $\mathrm{Fe}^{\mathrm{II}}(\mathrm{L})$ and the oxidation of $\mathrm{Fe}^{\mathrm{II}}(\mathrm{L})$ towards a better NO removal in this flue gas process.

For a better investigation of the bubble interactions under reactive mass transfer conditions, a second high speed camera has to be mounted to detect the bubble shape, bubble movement and bubble wake with its concentration from two sides. By detecting the volume change, the overall mass transfer will be detected from a $3 \mathrm{D}$ recalculation of the bubble volume. A detailed study of the concentration influence to the material properties of the $\mathrm{Fe}^{\mathrm{II}}$ (edta) system will follow.

\section{ACKNOWLEDGMENTS}

This work was supported by the German Research Foundation (DFG), Priority Program SPP1740 "Reactive Bubbly Flows" (DFG HL-67/1-1 \& KL624/18-1).

\section{REFERENCES}

1 Bork O., Schlueter M., Raebiger N. (2005) The impact of local phenomena on mass transfer in gas-liquid systems, Can. J. Chem. Eng. 83, 4, 658-666. 
2 Vasconcelos J.M.T., Orvalho S.P., Alves S.S. (2002) Gas-liquid mass transfer to single bubbles: effect of surface contamination, AIChE J. 48, 6, 1145-1154.

3 Vasconcelos J., Rodrigues J., Orvalho S., Alves S., Mendes R., Reis A. (2003) Effect of contaminants on mass transfer coefficients in bubble column and airlift contactors, Chem. Eng. Sci. 58, 8, 1431-1440.

4 Painmanakul P., Loubière K., Hébrard G., Mietton-Peuchot M., Roustan M. (2005) Effect of surfactants on liquid-side mass transfer coefficients, Chem. Eng. Sci. 60, 22, 6480-6491.

5 Hebrard G., Zeng J., Loubiere K. (2009) Effect of surfactants on liquid side mass transfer coefficients: a new insight, Chem. Eng. J. 148, 1, 132-138.

6 Sardeing R., Painmanakul P., Hébrard G. (2006) Effect of surfactants on liquid-side mass transfer coefficients in gasliquid systems: a first step to modeling, Chem. Eng. Sci. 61, 19, 6249-6260.

7 Ferreira A., Cardoso P., Teixeira J.A., Rocha F. (2013) pH influence on oxygen mass transfer coefficient in a bubble column. Individual characterization of $k_{\mathrm{L}}$ and $a$, Chem. Eng. Sci. 100, 145-152.

8 Dani A., Guiraud P., Cockx A. (2007) Local measurement of oxygen transfer around a single bubble by planar laser-induced fluorescence, Chem. Eng. Sci. 62, 24, 7245-7252.

9 Kück U.D., Schlüter M., Räbiger N. (2012) Local measurement of mass transfer rate of a single bubble with and without a chemical reaction, J. Chem. Eng. Jpn 45, 708-712.

10 Dietrich N., Francois J., Jimenez M., Cockx A., Guiraud P., Hébrard G. (2015) Fast measurements of the gas-liquid diffusion coefficient in the Gaussian wake of a spherical bubble, Chem. Eng. Technol. 38, 5, 941-946.

11 Jimenez M., Dietrich N., Grace J.R., Hebrard G. (2014) Oxygen mass transfer and hydrodynamic behaviour in wastewater: determination of local impact of surfactants by visualization techniques, Water Res. 58, 111-121.

12 Khinast J.G., Koynov A.A., Leib T.M. (2003) Reactive mass transfer at gas-liquid interfaces: impact of micro-scale fluid dynamics on yield and selectivity of liquid-phase cyclohexane oxidation, Chem. Eng. Sci. 58, 17, 3961-3971.

13 Aboulhasanzadeh B., Hosoda S., Tomiyama A., Tryggvason G. (2013) A validation of an embedded analytical description approach for the computations of high Schmidt number mass transfer from bubbles in liquids, Chem. Eng. Sci. 101, 165-174.

14 Aboulhasanzadeh B., Thomas S., Taeibi-Rahni M., Tryggvason G. (2012) Multiscale computations of mass transfer from buoyant bubbles, Chem. Eng. Sci. 75, 456-467.

15 Bothe D., Koebe M., Wielage K., Prüss J., Warnecke H.-J. (2004) Direct numerical simulation of mass transfer between rising gas bubbles and water, in: M. Sommerfeld (ed.), Bubbly Flows: Analysis, Modelling and Calculation, Springer Berlin Heidelberg, Berlin, Heidelberg, pp. 159-174.

16 Bothe D., Koebe M., Wielage K., Warnecke H.-J. (2003) VOF-simulations of mass transfer from single bubbles and bubble chains rising in aqueous solutions, ASME/JSME 2003 4th Joint Fluids Summer Engineering Conference, 6-10 July, Honolulu, Hawaii, USA, Vol. 2: Symposia, Parts A, B, and C, Paper No. FEDSM2003-45155, pp. 423-429.

17 Koynov A., Khinast J.G. (2004) Effects of hydrodynamics and Lagrangian transport on chemically reacting bubble flows, Chem. Eng. Sci. 59, 18, 3907-3927.
18 Koynov A., Khinast J.G., Tryggvason G. (2005) Mass transfer and chemical reactions in bubble swarms with dynamic interfaces, AIChE J. 51, 10, 2786-2800.

19 Fleischer C., Becker S., Eigenberger G. (1996) Detailed modeling of the chemisorption of $\mathrm{CO}_{2}$ into $\mathrm{NaOH}$ in a bubble column, Chem. Eng. Sci. 51, 10, 1715-1724.

20 Darmana D., Deen N., Kuipers J. (2005) Detailed modeling of hydrodynamics, mass transfer and chemical reactions in a bubble column using a discrete bubble model, Chem. Eng. Sci. 60, 12, 3383-3404.

21 Darmana D., Henket R., Deen N., Kuipers J. (2007) Detailed modelling of hydrodynamics, mass transfer and chemical reactions in a bubble column using a discrete bubble model: chemisorption of $\mathrm{CO}_{2}$ into $\mathrm{NaOH}$ solution, numerical and experimental study, Chem. Eng. Sci. 62, 9, 2556-2575.

22 Houghton W.T. (1966) Mass transfer with chemical reaction from single spheres, $P h D$ Thesis, McMaster University, Hamilton, Ontario.

23 Wylock C., Dehaeck S., Cartage T., Colinet P., Haut B. (2011) Experimental study of gas-liquid mass transfer coupled with chemical reactions by digital holographic interferometry, Chem. Eng. Sci. 66, 14, 3400-3412.

24 Stone J.R., Marletta M.A. (1994) Soluble guanylate cyclase from bovine lung: activation with nitric oxide and carbon monoxide and spectral characterization of the ferrous and ferric states, Biochemistry 33, 18, 5636-5640.

25 Blaesi E.J., Gardner J.D., Fox B.G., Brunold T.C. (2013) Spectroscopic and computational characterization of the NO adduct of substrate-bound $\mathrm{Fe}(\mathrm{II})$ cysteine dioxygenase: insights into the mechanism of $\mathrm{O}_{2}$ activation, Biochemistry 52, 35, 6040-6051.

26 Ignarro L.J. (1999) Nitric oxide: a unique endogenous signaling molecule in vascular biology (nobel lecture), Angew. Chem. Int. Ed. 38, 13-14, 1882-1892.

27 Harrop T.C. (2015) Chapter Five - New insights on $\{\mathrm{FeNO}\}^{n}$ $(n=7,8)$ systems as enzyme models and HNO donors, $A d v$. Inorg. Chem. 67, 243-263.

28 Franke A., van Eldik R. (2013) Factors that determine the mechanism of NO activation by metal complexes of biological and environmental relevance, Eur. J. Inorg. Chem. 2013, 4, 460-480.

29 Schneppensieper T., Wanat A., Stochel G., van Eldik R. (2002) Mechanistic information on the reversible binding of NO to selected iron(II) chelates from activation parameters, Inorg. Chem. 41, 9, 2565-2573.

30 Schneppensieper T., Wanat A., Stochel G., Goldstein S., Meyerstein D., van Eldik R. (2001) Ligand effects on the kinetics of the reversible binding of NO to selected aminocarboxylato complexes of iron(II) in aqueous solution, Eur. J. Inorg. Chem. 2001, 9, 2317-2325.

31 Xia Y., Zhao J., Li M., Zhang S., Li S., Li W. (2016) Bioelectrochemical reduction of Fe(II)EDTA-NO in a biofilm electrode reactor: performance, mechanism, and kinetics, Environ. Sci. Technol. 50, 7, 3846-3851.

32 Li W., Zhao J., Zhang L., Xia Y., Liu N., Li S., Zhang S. (2016) Pathway of FeEDTA transformation and its impact on performance of $\mathrm{NO}_{\mathrm{x}}$ removal in a chemical absorption-biological reduction integrated process, Sci. Rep. 6, 18876. 
33 Chen J., Wang L., Zheng J., Chen J. (2015) $\mathrm{N}_{2} \mathrm{O}$ production in the $\mathrm{Fe}(\mathrm{II})(\mathrm{EDTA})-\mathrm{NO}$ reduction process: the effects of carbon source and pH, Bioprocess Biosyst. Eng. 38, 7, 1373-1380.

34 Zhang S., Chen H., Xia Y., Liu N., Lu B.-H., Li W. (2014) Current advances of integrated processes combining chemical absorption and biological reduction for $\mathrm{NO}_{\mathrm{x}}$ removal from flue gas, Appl. Microbiol. Biotechnol. 98, 20, 8497-8512.

35 de Salas C., Heinrich M.R. (2014) Fixation and recycling of nitrogen monoxide through carbonitrosation reactions, Green Chem. 16, 6, 2982.

36 Liu N., Jiang Y., Zhang L., Xia Y., Lu B., Xu B., Li W., Li S. (2014) Evaluation of $\mathrm{NO}_{\mathrm{x}}$ removal from flue gas by a chemical absorption - biological reduction integrated system: glucose consumption and utilization pathways, Energy Fuels 28, 12, 7591-7598.

37 Xia Y., Shi Y., Zhou Y., Liu N., Li W., Li S. (2014) A new approach for $\mathrm{NO}_{\mathrm{x}}$ removal from flue gas using a biofilm electrode reactor coupled with chemical absorption, Energy Fuels 28, 5, 3332-3338.

38 Niu H., Leung D. (2010) A review on the removal of nitrogen oxides from polluted flow by bioreactors, Environ. Rev. 18, NA, 175-189.

39 van der Maas P., Harmsen L., Weelink S., Klapwijk B., Lens P. (2004) Denitrification in aqueous FeEDTA solutions, J. Chem. Technol. Biotechnol. 79, 8, 835-841.

40 Sander R. (2015) Compilation of Henry's law constants (version 4.0) for water as solvent, Atmos. Chem. Phys. 15, 8, 4399-4981.
41 Wolf M., Kluefers P. (2016) Structure and bonding of highspin nitrosyl-iron(II) compounds with mixed N,O-chelators and aqua ligands, Eur. J. Inorg. Chem., DOI: 10.1002/ ejic. 201601329.

42 Aas B., Kluefers P. (2016) The structural chemistry of stable high-spin nitrosyl-iron(II) compounds with aminecarboxylato co-ligands in aqueous solution, Eur. J. Inorg. Chem., DOI: 10.1002/ejic.201601330.

43 Simon M. (2015) Koaleszenz von Tropfen und Tropfenschwärmen, PhD Thesis, University of Kaiserslautern, Kaiserslautern, Germany.

44 Li H., Fang W. (1988) Kinetics of absorption of nitric oxide in aqueous iron(II)-EDTA solution, Ind. Eng. Chem. Res. 27, 5, 770-774.

45 Gambardella F., Alberts M.S., Winkelman J.G.M., Heeres E.J. (2005) Experimental and modeling studies on the absorption of NO in aqueous ferrous EDTA solutions, Ind. Eng. Chem. Res. 44, 12, 4234-4242.

46 Zacharia I.G., Deen W.M. (2005) Diffusivity and solubility of nitric oxide in water and saline, Ann. Biomed. Eng. 33, 2, 214-222.

\section{APPENDIX}

Manuscript submitted in September 2016 Manuscript accepted in February 2017 Published online in March 2017

TABLE A1

Description of ligands.

\begin{tabular}{c|l|c|c|c}
\hline Ligand & \multicolumn{1}{|c|}{ Name } & CAS-nr. & Chemical formula \\
\hline oda & $2,2^{\prime}$-Oxydiacetic acid & $110-99-6$ & $\mathrm{C}_{4} \mathrm{H}_{6} \mathrm{O}_{5}$ \\
\hline ida & Iminodiacetic acid & $142-73-4$ & $\mathrm{C}_{4} \mathrm{H}_{7} \mathrm{NO}_{4}$ \\
\hline edda & Ethylenediamine-N,N'-diacetic acid & $5657-17-0$ & $\mathrm{C}_{6} \mathrm{H}_{12} \mathrm{~N}_{2} \mathrm{O}_{4}$ \\
\hline edta & $\begin{array}{l}\text { Ethylenediaminetetraacetic } \\
\text { acid tetra-sodium salt } \\
\text { hydrate }\end{array}$ & 134.1 & $\mathrm{C}_{10} \mathrm{H}_{12} \mathrm{~N}_{2} \mathrm{Na}_{4} \mathrm{O}_{8} \bullet \mathrm{xH}_{2} \mathrm{O}$ \\
\hline hedtra & $\begin{array}{l}\text { N-(2-hydroxyethyl) } \\
\text { ethylenediaminetri-acetic acid } \\
\text { trisodium salt hydrate }\end{array}$ & $207386-87-6$ & 380.17 (anhydrous basis) \\
\hline
\end{tabular}

Cite this article as: M.W. Hlawitschka, M. Oßberger, C. Backes, P. Klüfers and H.-J. Bart (2017). Reactive Mass Transfer of Single NO Bubbles and Bubble Bouncing in Aqueous Ferric Solutions - A Feasibility Study, Oil Gas Sci. Technol 72, 11. 